\title{
IN VITRO SYMBIOTIC GERMINATION POTENTIALS OF SOME ANACAMPTIS, DACTYLORHIZA, ORCHIS AND OPHRYS TERRESTRIAL ORCHID SPECIES
}

\author{
ÇIĞ, A. ${ }^{1^{*}}-$ DEMIRER DURAK, E. ${ }^{2}-$ IŞLER, $^{3} .^{3}$ \\ ${ }^{1}$ Department of Horticulture, Faculty of Agriculture, Siirt University, Siirt, Turkey \\ ${ }^{2}$ Department of Plant Protection, Faculty of Agriculture, Yüzüncü Yll University, Van, Turkey \\ ${ }^{3}$ Department of Science and Mathematics, Faculty of Education, Yüzüncü Yll University \\ Van, Turkey \\ *Corresponding author \\ e-mail: arzucig@yahoo.com; phone: +90-531-623-1533
}

(Received 23 $3^{\text {rd }}$ May 2018; accepted $31^{\text {st }}$ Jul 2018)

\begin{abstract}
Germination and propagation of terrestrial orchids is highly challenging due to their small size seeds and absence of endosperms. Some orchid species are extremely dependent on fungi for germination of their seeds. Although germination occurs symbiotically between the seed and the fungus, it is not coincidental that fungus species are specific to orchid species. Aim of this study is to show the impact of the fungi, isolated from the tubers of ten naturally grown species of orchids, collected from mountainous area of Van province, Turkey, on in vitro symbiotic germination of the seeds. The collected orchids species were Dactylorhiza romana (Seb.) Soo subsp. georgica (Klinge) Soo ex Renz \& Taub., Orchis pinetorum Boissier \& Kotschy, Orchis spitzelii Saut. ex W.D.J. Koch, Orchis coriophora L., Orchis collina Banks \& Solander, Orchis anatolica Boiss., Orchis simia Lamarck, Ophrys straussii H. Fleischmann \& Bornmüller, Dactylorhiza umbrosa (Kar. \& Kir.) Nevski, Anacamptis pyramidalis (L.) L. C. Rich. In the study from orchid tubers, Rhizoctonia sp., Aspergillus sp., Alternaria sp., Penicillium sp., Trichoderma sp. and Fusarium sp. fungi species are isolated. Firstly, orchid seeds and fungal isolates placed in oat culture medium were transferred to Van Waes \& Debergh culture medium in subculture. The highest germination rates obtained in the seeds are $71.19 \%$ in Dactylorhiza romana subsp. georgica species with Rhizoctonia sp.; $78.26 \%$ in Orchis pinetorum species with Penicillium sp.; $27.77 \%$ in Orchis spitzelii species with Fusarium sp.; $83.07 \%$ in Orchis coriophora species with Rhizoctonia sp.; $75.00 \%$ in Orchis collina species with Fusarium sp.; $38.88 \%$ in Orchis anatolica species with Alternaria sp.; 73.91\% in Orchis simia species with Fusarium sp.; $91.60 \%$ in Ophrys straussii species with Fusarium sp.; $93.75 \%$ in Dactylorhiza umbrosa species with Fusarium sp. and $56.00 \%$ in Anacamptis pyramidalis species with Rhizoctonia sp. At the end of the study, it was understood that the fungi isolated from their own or other tubers had different effects on the germination of each orchid species.
\end{abstract}

Keywords: fungal isolates, in vitro, mycorrhiza effect, symbiotic germination, terrestrial orchid

\section{Introduction}

The most distinctive features of the orchid seeds are their very small size, absence of endosperm and undeveloped embryo. These seeds have a length of 0.25-1.2 mm, width of 0.09-0.27 mm and weight of 0.3-1.4 mg (Arditti, 1967). The orchids grown at high altitudes occasionally fail to grow and set seed due to low temperatures or the ones grown under dense forests grow slowly and cannot reach to a desired level of development due to lack of light (Sezik, 1984). Thus, in addition to appropriate temperature, light, oxygen, moisture and soil conditions required in the microclimate of the environment in which the seed fall to germinate, an appropriate symbiotic relationship should be established with a mycorrhizal fungus for germination of the 
seeds (Sezik, 1984). As the orchid seeds do not contain nutrient reserves, successful germination cannot be achieved unless a carbohydrate source, such as glucose, is provided (Ingold and Hudson, 1993).

The symbiotic capacity of a fungal isolate depends primarily on the nature of the isolate and then the orchid species with which it coexists. The results obtained on the existence of a specificity between orchid species and mycorrhizal fungi indicate that there is no strict specificity at the species-species level, and that, on the other hand, orchid-fungus relationships are not entirely random. According to Batty et al. (2001), terrestrial orchids may have narrow or broad potential specificity (Warcup, 1981; Alexander and Hadley, 1983; Muir, 1989), but the specificity of their associations with endophytes in natural habitats is still poorly understood. The specificity of the orchidmycorrhiza association is variable between species (Steinfort et al., 2010). An orchid may form mycorrhizal associations with more than one fungal species, and a fungal species might associate with more than one orchid under in situ conditions (Bonnardeaux et al., 2007; Otero et al., 2004).

When these relations existing in the nature are moved to the laboratory conditions; the fungal isolates are isolated from the orchid tubers and roots and inoculated into the medium. In this study, the impacts of the fungal isolates isolated from orchid tubers, collected from the nature and inoculated into nutrient medium, on germination of the seeds are determined.

\section{Material and methods}

The material of the research consists of orchid seeds and fungi obtained from the tubers of the plants. The plants used in the research are naturally grown in Van province, Turkey, collected from Gevaş District Altınsaç neighbourhood in July-2014 when the plants formed capsules, and identified according to Davis (1984).

\section{Orchid species}

The orchid species examined in the study are Dactylorhiza romana (Seb.) Soo subsp. georgica (Klınge) Soo ex Renz \& Taub., Orchis pinetorum Boissier \& Kotschy, Orchis spitzelii Saut. ex W.D.J. Koch, Orchis coriophora L., Orchis collina Banks \& Solander, Orchis anatolica Boiss., Orchis simia Lamarck, Ophrys straussii H. Fleischmann \& Bornmüller, Dactylorhiza umbrosa (Kar. \& Kir.) Nevski, Anacamptis pyramidalis (L.) L. C. Rich.

Dactylorhiza romana subsp. georgica, Orchis pinetorum ve Orchis spitzelii species

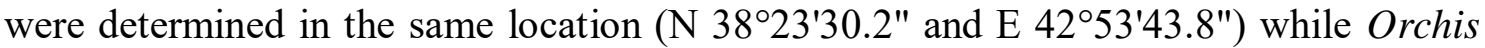
coriophora and Dactylorhiza umbrosa species were obtained in the same location (N 38 $24^{\prime} 16.2^{\prime \prime}$ and E 42 53'76.6"). Anacamptis pyramidalis, Orchis collina, Orchis simia, and Ophrys straussii species were collected from N 38 $23^{\prime} 61.7^{\prime \prime}$ and E 42 $55^{\prime} 03.2^{\prime \prime}$ coordinates while Orchis anatolica species was collected from N 38 $23^{\prime} 59.3^{\prime \prime}$ and E 42 54 '98.1" coordinate (Table 1 and Fig. 1).

\section{Fungi}

Fungi obtained from isolations in tuber samples, collected during seed collection, are used. 
Table 1. GPS coordinates where orchid species are collected

\begin{tabular}{|c|c|c|c|c|}
\hline No & Orchid species & \multicolumn{2}{|c|}{ GPS Coordinates } & Altitute (m) \\
\hline 1 & Dactylorhiza romana subsp. georgica & N $38^{\circ} 23^{\prime} 30.2^{\prime \prime}$ & E $42^{\circ} 53^{\prime} 43.8^{\prime \prime}$ & 1864 \\
\hline 2 & Orchis pinetorum & N $38^{\circ} 23^{\prime} 30.2^{\prime \prime}$ & E $42^{\circ} 53^{\prime} 43.8^{\prime \prime}$ & 1864 \\
\hline 3 & Orchis spitzelii & N $38^{\circ} 23^{\prime} 30.2^{\prime \prime}$ & E $42^{\circ} 53^{\prime} 43.8^{\prime \prime}$ & 1864 \\
\hline 4 & Orchis coriophora & N $38^{\circ} 24^{\prime} 16.2^{\prime \prime}$ & E $42^{\circ} 53^{\prime} 76.6^{\prime \prime}$ & 1631 \\
\hline 5 & Dactylorhiza umbrosa & N $38^{\circ} 24^{\prime} 16.2^{\prime \prime}$ & E $42^{\circ} 53^{\prime} 76.6^{\prime \prime}$ & 1631 \\
\hline 6 & Anacamptis pyramidalis & N $38^{\circ} 23^{\prime} 61.7^{\prime \prime}$ & E $42^{\circ} 55^{\prime} 03.2^{\prime \prime}$ & 1724 \\
\hline 7 & Orchis collina & N $38^{\circ} 23^{\prime} 61.7^{\prime \prime}$ & E $42^{\circ} 55^{\prime} 03.2^{\prime \prime}$ & 1724 \\
\hline 8 & Orchis simia & N $38^{\circ} 23^{\prime} 61.7^{\prime \prime}$ & E $42^{\circ} 55^{\prime} 03.2^{\prime \prime}$ & 1724 \\
\hline 9 & Ophrys straussii & N $38^{\circ} 23^{\prime} 61.7^{\prime \prime}$ & E $42^{\circ} 55^{\prime} 03.2^{\prime \prime}$ & 1724 \\
\hline 10 & Orchis anatolica & N 38²3'59.3" & E $42^{\circ} 54^{\prime} 98.1 "$ & 1724 \\
\hline
\end{tabular}

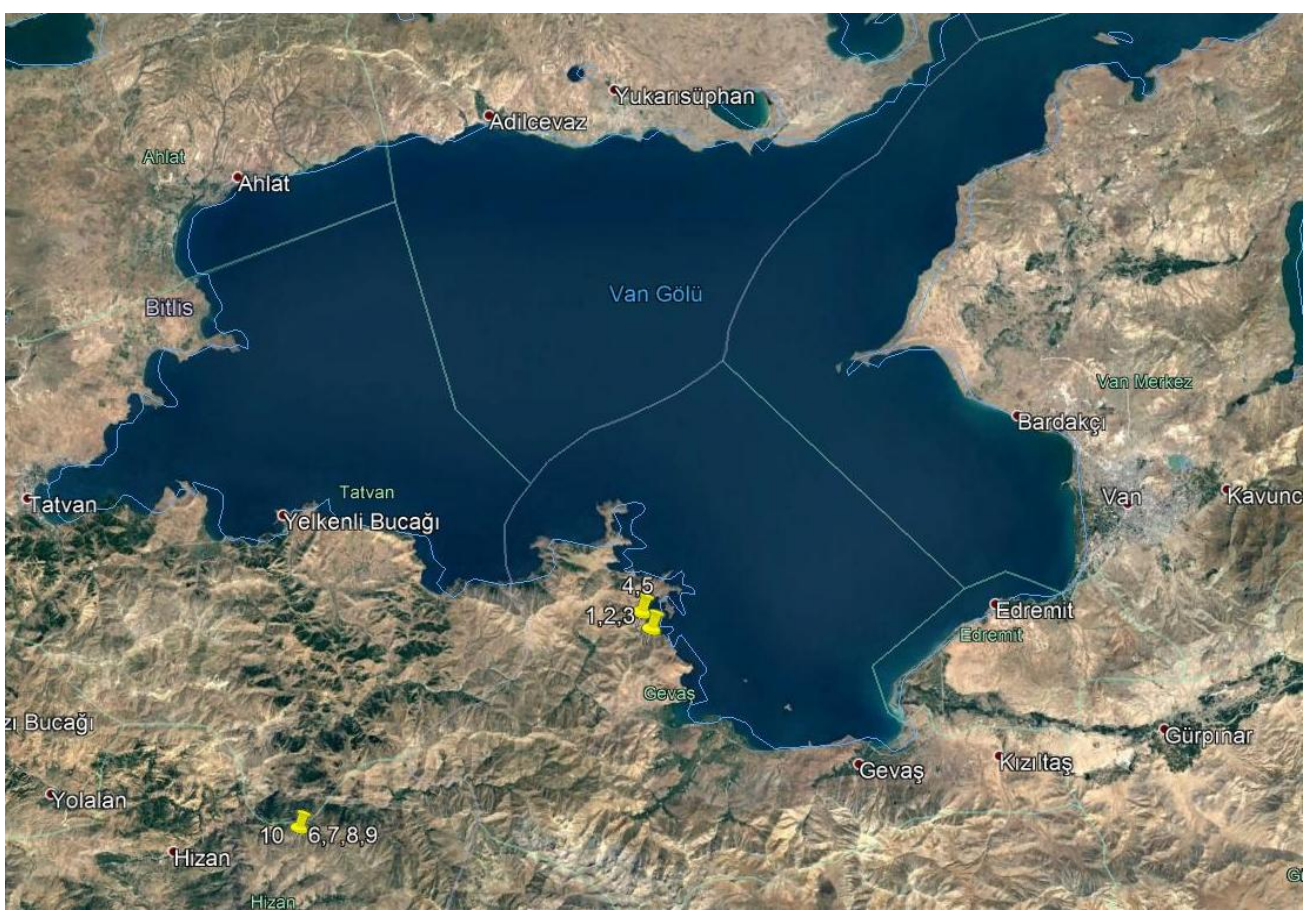

Figure 1. Locations where orchid species are collected (Google Earth, 2018)

\section{Surface sterilization of the seeds}

Orchid seeds are sterilized in small envelopes made from coarse filter papers as they are very small and have a dusty structure. Seeds of each species weighting $100 \mathrm{mg}$ are enveloped and used for experiments. For each experiment, $100 \mathrm{mg}$ of the seeds were planted in total of 9 petri dishes containing Potato Dextrose Agar (PDA) media in 3 replicates, 3 pots in each replicate.

The seeds were shaken for 5 min with $2 \%$ sulfuric acid, sterilized with 1-2 drops of Tween-20 and 10\% commercial bleach for $12 \mathrm{~min}$ and then rinsed 3 times with sterile distilled water before sowing to Çı̆̆ and Yılmaz (2017). 


\section{Fungus isolation from tubers}

The orchid tubers, washed from the soil in the tap water, were shaken in the sterilized cabinet for $3 \mathrm{~min}$ in $3 \%$ bleach solution and then rinsed 3 times with sterile distilled water and wiped with sterilized drying papers. 2-3 pieces of tuber, cut into sections with 0.5-1 cm length with scalpel, were planted in PDA petri dishes and incubated for 34 days at $24{ }^{\circ} \mathrm{C}$. The PDA medium was prepared with $39 \mathrm{~g} / 1$ potato dextrose agar dose (Zettler et al., 2001; Sharma et al., 2003) and sterilized for $20 \mathrm{~min}$ in an autoclave operating at $121{ }^{\circ} \mathrm{C}$ and 1.2 atmosphere pressure.

Developed fungal hyphae were identified on light microscope after being transferred to water agar (WA, $15 \mathrm{~g} / \mathrm{l}$ ) petri dishes and stored in refrigerator in glass tubes. Fungus isolation procedures and identification were done in Mycology Laboratory of the Department of Plant Protection, Faculty of Agriculture at Yüzüncü Y1l University.

\section{Identification of isolates}

Morphological and microscopic features of the fungi incubated in PDA and WA for 7 days at $25^{\circ} \mathrm{C}$ were used in identification of the isolates obtained in the study (Barnett, 1965; Booth, 1971; Burgess et al., 1994; Domsch et al., 1980; Gilman, 1959; Singh et al., 1991; Ogoshi, 1975). Identification of Trichoderma species was done by using the interactive key http://nt.arsgrin.gov/taxadescriptions/keys/TrichodermaIndex.cfm (Samuel et al., 2006).

\section{Composition of the oat medium (OM)}

In order to create the oat medium described by Clements and Ellyard (1979), $2.5 \mathrm{~g}$ milled and powdered oat was boiled in $1000 \mathrm{ml}$ of distilled water for one hour and drained from the gauze. The $\mathrm{pH}$ of the cooled medium was adjusted to 5.5 and it was autoclaved by adding $7 \mathrm{~g} / \mathrm{l}$ agar as in the PDA medium.

\section{Seed sowing in symbiotic culture medium}

The fungi used in the study were planted in petri dishes containing PDA in advance and $0.5 \mathrm{~cm}$ discs were taken with cork borer when they were 10 days old. Each disk was placed on one side of the petri dish containing OM, which is a symbiotic medium. Petri dishes were incubated in the dark at $24^{\circ} \mathrm{C}$ for a couple of days. Seed sowing was done on the other side of the petri dishes where there is no fungus. The petri dishes were kept at $23 \pm 1{ }^{\circ} \mathrm{C}$ in the dark during germination. The seeds were taken to Van Waes \& Debergh (VWD) (1986) culture medium while sub-culturing.

\section{Statistically analysis}

The data were analyzed using the statistical software package SPSS. The means were grouped using the Duncan multiple comparison test (Düzgüneş et al., 1987).

\section{Results and discussions}

\section{Fungus isolation and identification}

Six orchid tuber samples/orchid species were used for fungal isolation. The identification of the fungi was done by the references after isolations from tuber 
samples. Rhizoctonia sp., Aspergillus sp., Fusarium sp., Penicillium sp., Trichoderma sp., and Alternaria sp. were isolated from orchid tubers. The identification was based on morphological and microscopic features (Table 2).

Table 2. Morphological and microscopic features of the fungi isolated from tuber samples

\begin{tabular}{|c|c|c|c|}
\hline \multirow{2}{*}{ Fungi } & \multicolumn{2}{|c|}{ Morphological and microscopic features } & \multirow{2}{*}{ References } \\
\hline & Colony color in PDA & Shape of conidia & \\
\hline Rhizoctonia sp. & White/brown & No conidia & Ogoshi, 1975 \\
\hline Aspergillus sp. & Black/green & Spherical & Singh et al., 1991; Barnett, 1965 \\
\hline Fusarium sp. & Pink/orange/purple & $\begin{array}{c}\text { Ovoid to elongated } \\
\text { (macroconidia and microconidia) }\end{array}$ & Booth, 1971; Burgess et al., 1994 \\
\hline Penicillium sp. & Green & Ellipsoidal & $\begin{array}{l}\text { Domsch et al., 1980; Gilman, 1959; } \\
\text { Singh et al., } 1991\end{array}$ \\
\hline Trichoderma sp. & Green & Globose, subglobose/ellipsoidal & Samuels et al., 2006 \\
\hline Alternaria sp. & Brown/black & Ovoid/ ellipsoidal & Domsch et al., 1980; Gilman, 1959 \\
\hline
\end{tabular}

Rhizoctonia sp. and Aspergillus sp. fungi from Dactylorhiza romana subsp. georgica (1) species; Fusarium sp. and Penicillium sp. fungi from Orchis pinetorum (2) species; Rhizoctonia sp. and Fusarium sp. fungi from Orchis spitzelii (3) species; Trichoderma sp., Fusarium sp. and Penicillium sp. fungi from Orchis coriophora (4) species; Alternaria sp. fungus from Orchis collina (5) species; Fusarium sp. fungus from Orchis simia (7) species; Fusarium sp., Aspergillus sp. and Penicillium sp. fungi from Ophrys straussii (8) species,; Rhizoctonia sp., Fusarium sp. and Alternaria sp. fungi from Dactylorhiza umbrosa (9) species (3 isolates); Fusarium sp., Alternaria sp., Penicillium sp. and Aspergillus sp. fungi from Anacamptis pyramidalis (10) species were isolated, while no fungus was isolated from Orchis anatolica (6) species (Table 3).

Fungi were infected not only in the orchid species they were isolated from, but also into the cultures where the seeds of other species were planted. Photographs of symbiotic germination were taken with OLYMPUS SZ61 binocular microscope dp20 camera, 10X x 1.2 software (Fig. 2).

Table 3. Orchid species and isolated fungi

\begin{tabular}{c|c|c|c|c|c|c}
\hline \multirow{2}{*}{ Species } & \multicolumn{6}{|c}{ Fungi } \\
\cline { 2 - 7 } & $\begin{array}{c}\text { Rhizoctonia } \\
\text { sp. }\end{array}$ & $\begin{array}{c}\text { sspergillus } \\
\text { sp. }\end{array}$ & $\begin{array}{c}\text { Fusarium } \\
\text { sp. }\end{array}$ & $\begin{array}{c}\text { Penicillium } \\
\text { sp. }\end{array}$ & $\begin{array}{c}\text { Trichoderma } \\
\text { sp. }\end{array}$ & $\begin{array}{c}\text { Alternaria } \\
\text { sp. }\end{array}$ \\
\hline $\begin{array}{c}\text { Dactylorhiza romana } \text { subsp. } \\
\text { georgica (1) }\end{array}$ & $\mathrm{R}$ & $\mathrm{As}$ & - & - & - & - \\
Orchis pinetorum (2) & - & - & $\mathrm{F}$ & $\mathrm{P}$ & - & - \\
Orchis spitzelii (3) & $\mathrm{R}$ & - & $\mathrm{Fo}$ & - & - & - \\
Orchis coriophora (4) & - & - & $\mathrm{Fe}$ & $\mathrm{P}$ & $\mathrm{T}$ & - \\
Orchis collina (5) & - & - & - & - & - & Alt \\
Orchis anatolica (6) & - & - & - & - & - & - \\
Orchis simia (7) & - & - & F & - & - & - \\
Ophrys straussii (8) & - & As & Fs & P & - & - \\
Dactylorhiza umbrosa (9) & R, R1, R2 & - & F & - & - & Alt \\
Anacamptis pyramidalis (10) & - & As & F & P & - & Alt \\
\hline
\end{tabular}

*Each plant species was coded with a number 


\section{Symbiotic germination}

Isolated fungal isolates were shown like Rhizoctonia (R, R1, R2), Aspergillus (As), Fusarium (F, Fo, Fs), Penicillium (P), Trichoderma (T) and Alternaria (Alt) codes.

Table 4. The effects of isolated fungi on the germination of orchid seeds

\begin{tabular}{|c|c|c|c|c|c|c|c|c|c|c|}
\hline \multirow[b]{2}{*}{ Fungi } & \multicolumn{10}{|c|}{ Germination percentage $(\%)$} \\
\hline & $\begin{array}{c}\text { Species } \\
1\end{array}$ & $\begin{array}{c}\text { Species } \\
2\end{array}$ & \begin{tabular}{|c|} 
Species \\
3
\end{tabular} & \begin{tabular}{|c|} 
Species \\
4
\end{tabular} & $\begin{array}{c}\text { Species } \\
5\end{array}$ & $\begin{array}{c}\text { Species } \\
6\end{array}$ & $\begin{array}{c}\text { Species } \\
7\end{array}$ & $\begin{array}{c}\text { Species } \\
8\end{array}$ & $\begin{array}{c}\text { Species } \\
9\end{array}$ & $\begin{array}{c}\text { Species } \\
10\end{array}$ \\
\hline $1 \mathrm{As}$ & & & & & & & $18.18 \mathrm{~h}$ & & 16.661 & \\
\hline $1 \mathrm{R}$ & $71.19 \mathrm{a}^{*}$ & & & $45.23 \mathrm{f}$ & $20.20 \mathrm{i}$ & $6.66 \mathrm{~d}$ & $34.78 \mathrm{~d}$ & & $53.84 \mathrm{~h}$ & $18.91 \mathrm{kl}$ \\
\hline $2 \mathrm{~F}$ & & & & $39.47 \mathrm{~g}$ & $64.00 \mathrm{c}$ & & $73.91 \mathrm{a}$ & $91.60 \mathrm{a}$ & $63.79 \mathrm{e}$ & $37.23 \mathrm{e}$ \\
\hline $2 \mathrm{P}$ & & & & $33.33 \mathrm{~h}$ & & & & $15.38 \mathrm{k}$ & $70.86 \mathrm{~d}$ & $44.44 \mathrm{~cd}$ \\
\hline $3 \mathrm{Fo}$ & $40.00 \mathrm{e}$ & & $27.77 \mathrm{a}$ & $61.53 \mathrm{~d}$ & $42.64 \mathrm{f}$ & & & $56.25 \mathrm{e}$ & $54.85 \mathrm{gh}$ & $22.22 \mathrm{hi}$ \\
\hline $3 R$ & & & $16.00 \mathrm{c}$ & $48.38 \mathrm{e}$ & $41.66 \mathrm{f}$ & & & $42.85 \mathrm{~g}$ & $54.54 \mathrm{gh}$ & $56.00 \mathrm{a}$ \\
\hline $4 \mathrm{Fe}$ & $26.47 \mathrm{f}$ & & & $41.46 \mathrm{~g}$ & $15.38 \mathrm{j}$ & & $35.00 \mathrm{~d}$ & $83.33 \mathrm{~b}$ & $60.37 \mathrm{f}$ & \\
\hline $4 \mathrm{P}$ & & $31.57 \mathrm{c}$ & & & $33.33 \mathrm{~g}$ & & $31.25 \mathrm{e}$ & & $56.49 \mathrm{~g}$ & \\
\hline $4 \mathrm{~T}$ & $17.64 \mathrm{~g}$ & & & $65.86 \mathrm{c}$ & $68.18 \mathrm{~b}$ & $29.72 \mathrm{~b}$ & $66.66 \mathrm{~b}$ & $18.18 \mathrm{j}$ & $69.54 \mathrm{~d}$ & $20.00 \mathrm{jk}$ \\
\hline 5Alt & & & & & $48.59 \mathrm{e}$ & $38.88 \mathrm{a}$ & & $79.78 \mathrm{c}$ & $52.94 \mathrm{~h}$ & \\
\hline $7 \mathrm{~F}$ & $55.80 \mathrm{c}$ & & & $27.58 \mathrm{i}$ & & $14.28 \mathrm{c}$ & $25.98 \mathrm{f}$ & $57.14 \mathrm{e}$ & $79.16 \mathrm{~b}$ & $28.57 \mathrm{~g}$ \\
\hline $8 \mathrm{As}$ & & & & $36.12 \mathrm{~h}$ & $27.97 \mathrm{~h}$ & & $37.50 \mathrm{c}$ & & $37.40 \mathrm{k}$ & $42.85 \mathrm{~d}$ \\
\hline $8 \mathrm{Fs}$ & $45.68 \mathrm{~d}$ & & & $29.62 \mathrm{i}$ & & & & $15.38 \mathrm{k}$ & $41.17 \mathrm{j}$ & \\
\hline $8 \mathrm{P}$ & & $78.26 \mathrm{a}$ & & $60.00 \mathrm{~d}$ & $62.74 \mathrm{c}$ & & & $20.83 \mathrm{i}$ & $50.00 \mathrm{i}$ & \\
\hline 9Alt & $37.63 \mathrm{e}$ & & & $66.66 \mathrm{c}$ & $66.17 \mathrm{~b}$ & & $37.50 \mathrm{c}$ & $15.00 \mathrm{k}$ & $68.75 \mathrm{~d}$ & $53.33 \mathrm{~b}$ \\
\hline $9 \mathrm{~F}$ & & & & $80.95 \mathrm{a}$ & $27.94 \mathrm{~h}$ & & $25.00 \mathrm{f}$ & & 17.141 & $44.76 \mathrm{c}$ \\
\hline $9 \mathrm{R}$ & $45.78 \mathrm{~d}$ & & $20.83 \mathrm{~b}$ & $83.07 \mathrm{a}$ & $18.75 \mathrm{i}$ & $38.29 \mathrm{a}$ & & $30.00 \mathrm{~h}$ & $61.29 \mathrm{f}$ & 17.561 \\
\hline 9R1 & & & & $77.77 \mathrm{~b}$ & $50.00 \mathrm{e}$ & & & $65.38 \mathrm{~d}$ & 17.641 & $21.05 \mathrm{ij}$ \\
\hline 9R2 & & & & $66.66 \mathrm{c}$ & $58.33 \mathrm{~d}$ & & & 11.421 & $76.77 \mathrm{c}$ & \\
\hline 10Alt & $63.21 \mathrm{~b}$ & & & $59.21 \mathrm{~d}$ & $15.00 \mathrm{j}$ & & $22.36 \mathrm{~g}$ & & $74.67 \mathrm{c}$ & $7.93 \mathrm{n}$ \\
\hline $10 \mathrm{As}$ & & $48.27 \mathrm{~b}$ & & $13.33 \mathrm{j}$ & $10.63 \mathrm{k}$ & & & $9.19 \mathrm{~m}$ & $41.30 \mathrm{j}$ & $23.07 \mathrm{~h}$ \\
\hline $10 \mathrm{~F}$ & $57.69 \mathrm{c}$ & & & $67.85 \mathrm{c}$ & $75.00 \mathrm{a}$ & & $12.82 \mathrm{i}$ & & $93.75 \mathrm{a}$ & $34.04 \mathrm{f}$ \\
\hline $10 \mathrm{P}$ & & $34.32 \mathrm{c}$ & & $40.00 \mathrm{~g}$ & $16.00 \mathrm{j}$ & & & $50.00 \mathrm{f}$ & & $12.50 \mathrm{~m}$ \\
\hline
\end{tabular}

*Means followed by the same letter in the line indicate no statistical difference at $5 \%$ level

Orchid species 1: Dactylorhiza romana subsp. georgica, 2: Orchis pinetorum, 3: Orchis spitzelii, 4: Orchis coriophora, 5: Orchis collina, 6: Orchis anatolica, 7: Orchis simia, 8: Ophrys straussii, 9: Dactylorhiza umbrosa, and 10: Anacamptis pyramidalis

Fungal isolates: Aspergillus (As), Alternaria (Alt), Fusarium (F, Fo, Fs), Penicillium (P), Rhizoctonia (R, R1, R2), and Trichoderma (T) 


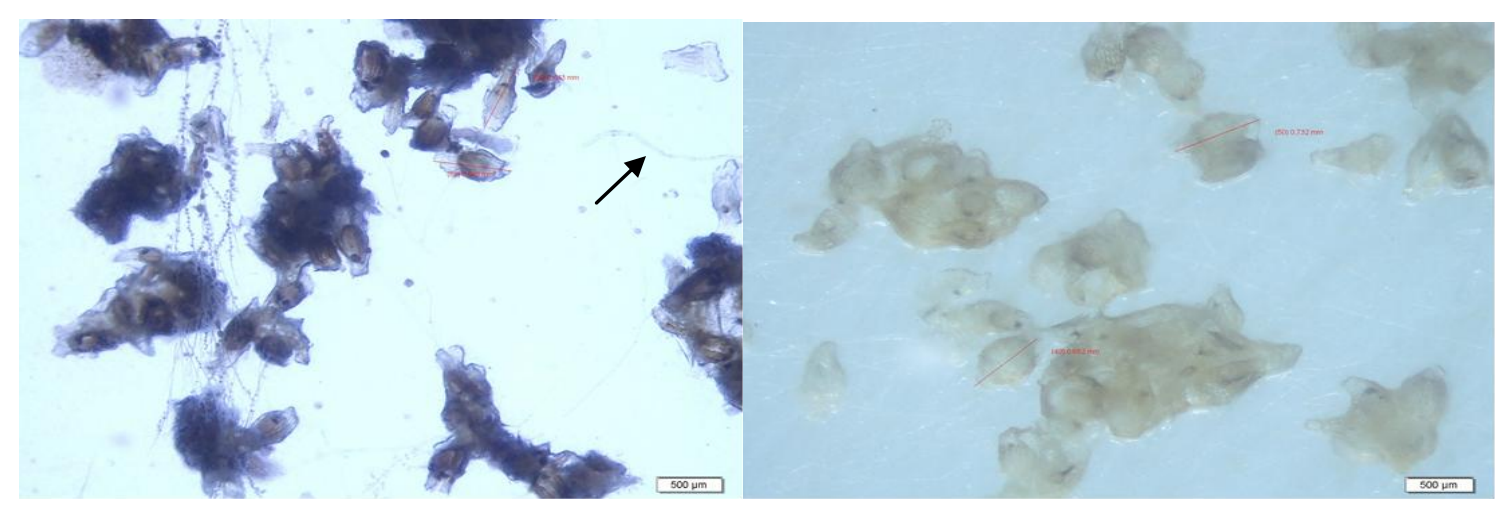

Figure 2. Symbiotic germination

The effects of the isolated fungi on the germination of orchid seeds were found statistically significant $(\mathrm{p}<0.05)$ (Table 4). $71.19 \%$ germination rate is observed in Rhizoctonia $(\mathrm{R})$ fungus obtained from the tuber of $D$. romana subsp. georgica (species number 1) (Fig. 3). No germination is observed with the fungi obtained from tubers of species number 2 O. pinetorum (Fig. 4), while the impact of $\mathrm{R}$ and Fo isolated from the tubers of species number 3 O. spitzelii on germination is found as $16 \%$ and $27.77 \%$, respectively (Fig. 5). $\mathrm{T}$ isolate, isolated from the tubers of species number $4 O$. coriophora, provided $65.86 \%$ germination rate (Fig. 6). From the species number $5 O$. collina, only sub-culturing is done and the impact of its own seeds on germination was determined as $48.59 \%$ (Fig. 7). As no fungus was isolated from the tubers of species number $6 \mathrm{O}$. anatolica, germination is obtained using fungi isolated from tubers of other orchid species (Fig. 8). In the symbiotic germination between the seeds of species number $7 \mathrm{O}$. simia and $\mathrm{F}$ fungus isolated from its tubers, a success rate of $25.98 \%$ is achieved (Fig. 9). Fs and $\mathrm{P}$ fungi isolated from the tubers of species number $8 O$. straussii had impacts of $15.38 \%$ and $20.83 \%$ respectively on germination of its own seeds (Fig. 10). R, R1, R2, Alt and F fungi isolated from the tubers of species number 9 D. umbrosa had impacts of $61.29 \%, 17.64 \%, 76.77 \%, 68.75 \%$ and $17.14 \%$ on germination of its own seeds, respectively (Fig. 11). F, Alt, As and P fungi isolated from the tubers of species number 10 A. pyramidalis had impacts of $34.04 \%, 7.93 \%$, $23.07 \%$ and $12.5 \%$ respectively on germination of its own seeds (Fig. 12).

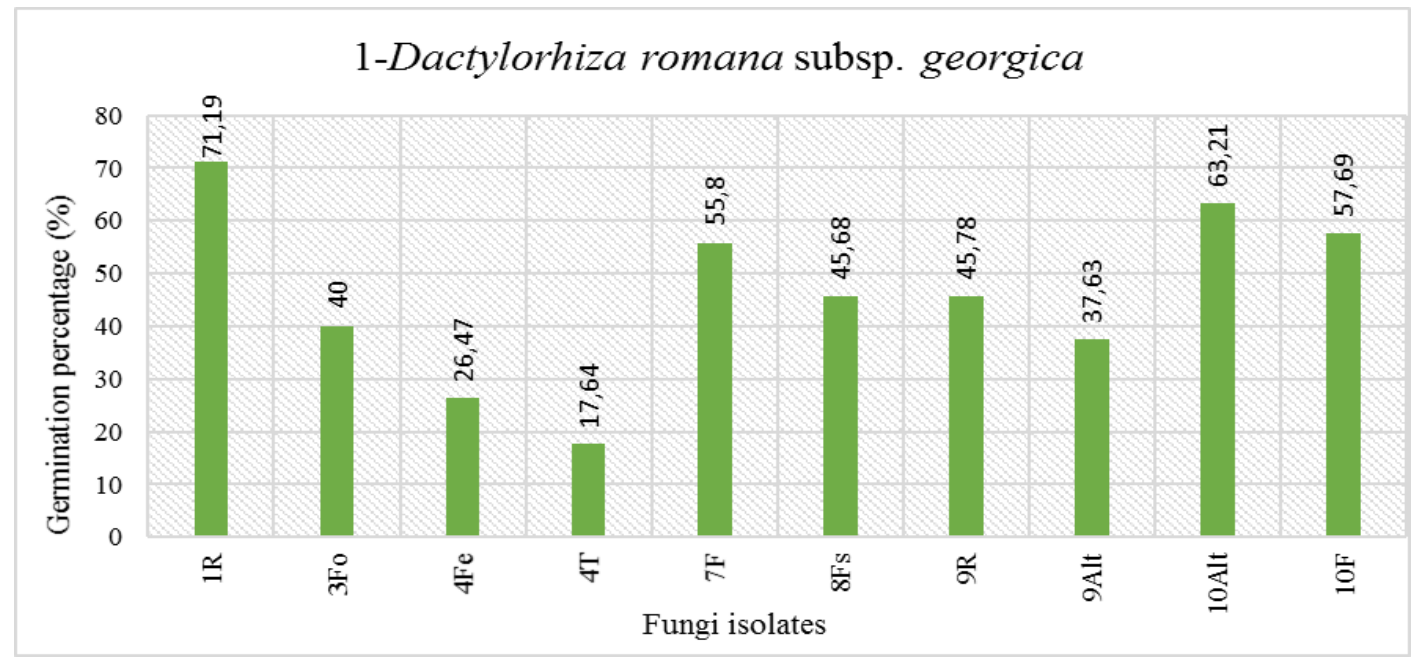

Figure 3. Effects on the germination rates of fungi on D. romana subsp. georgica germination 


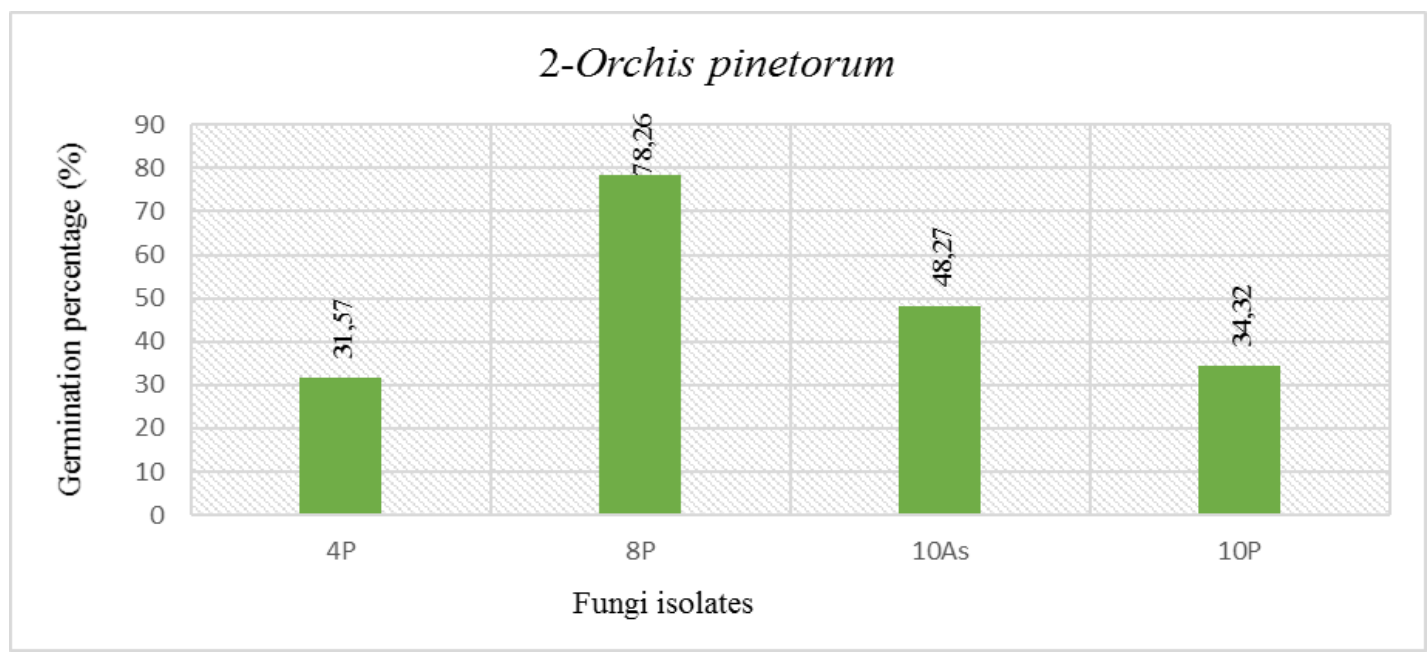

Figure 4. Effects on the germination rates of fungi on $O$. pinetorum germination

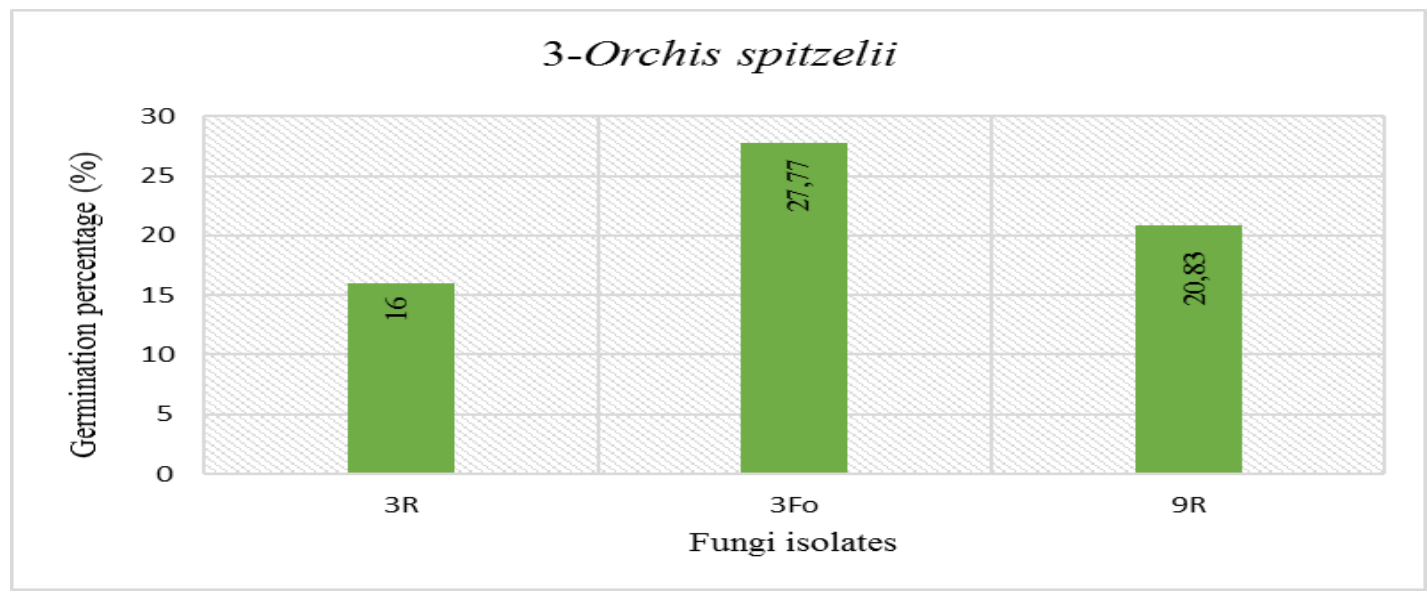

Figure 5. Effects on the germination rates of fungi on O. spitzelii germination

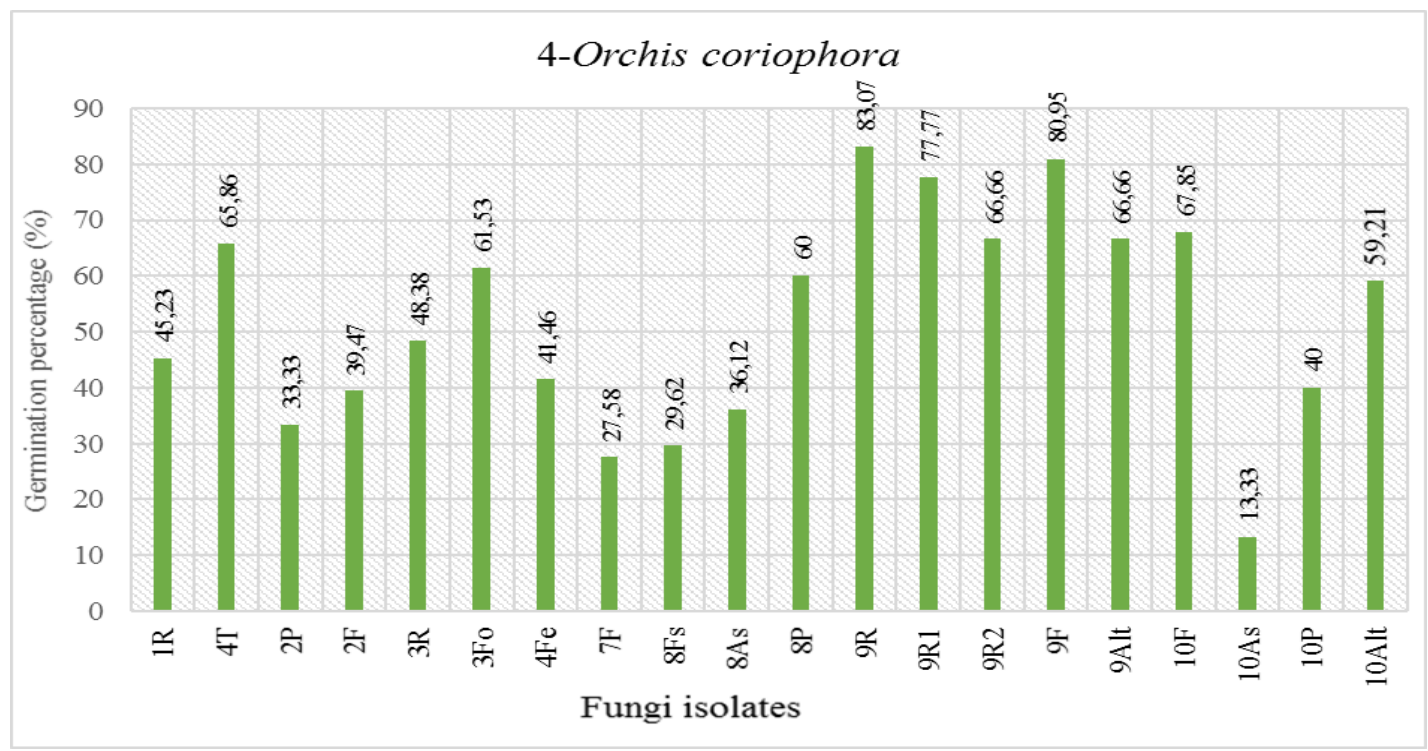

Figure 6. Effects on the germination rates of fungi on $O$. coriophora germination 


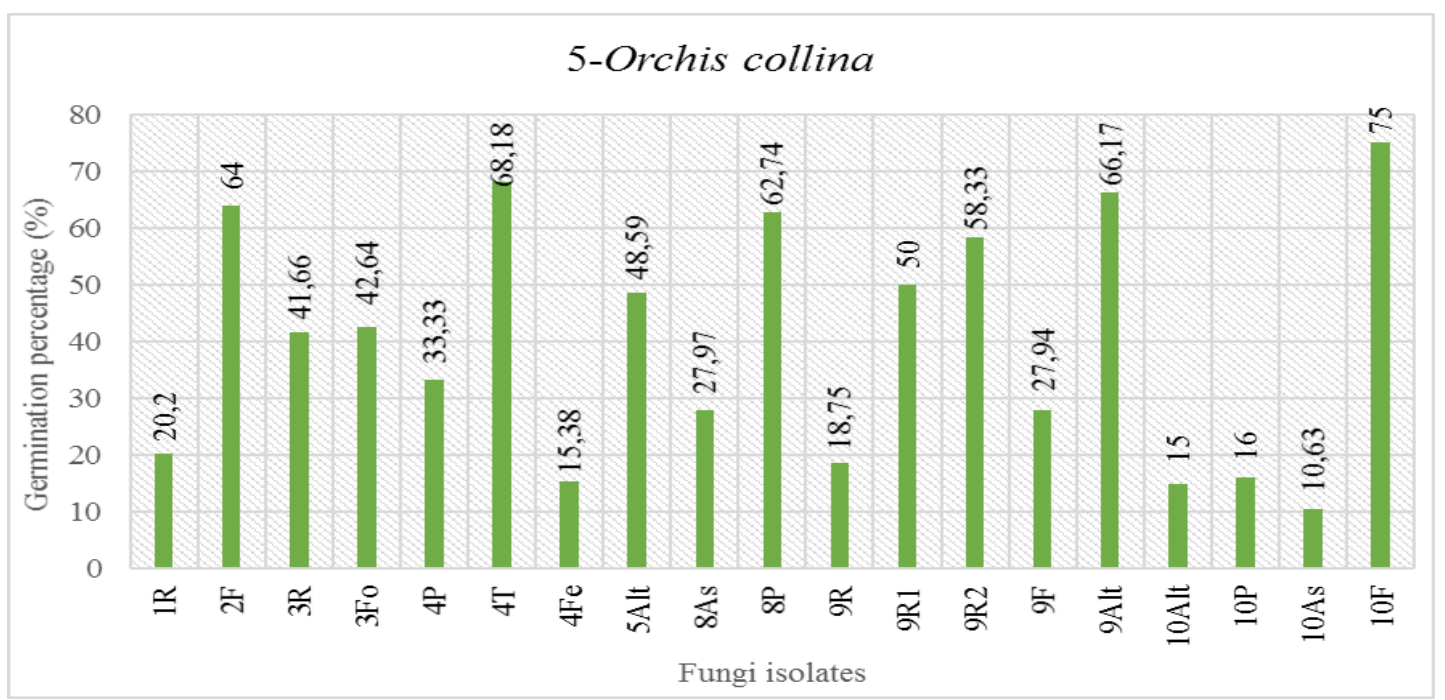

Figure 7. Effects on the germination rates of fungi on $O$. collina germination

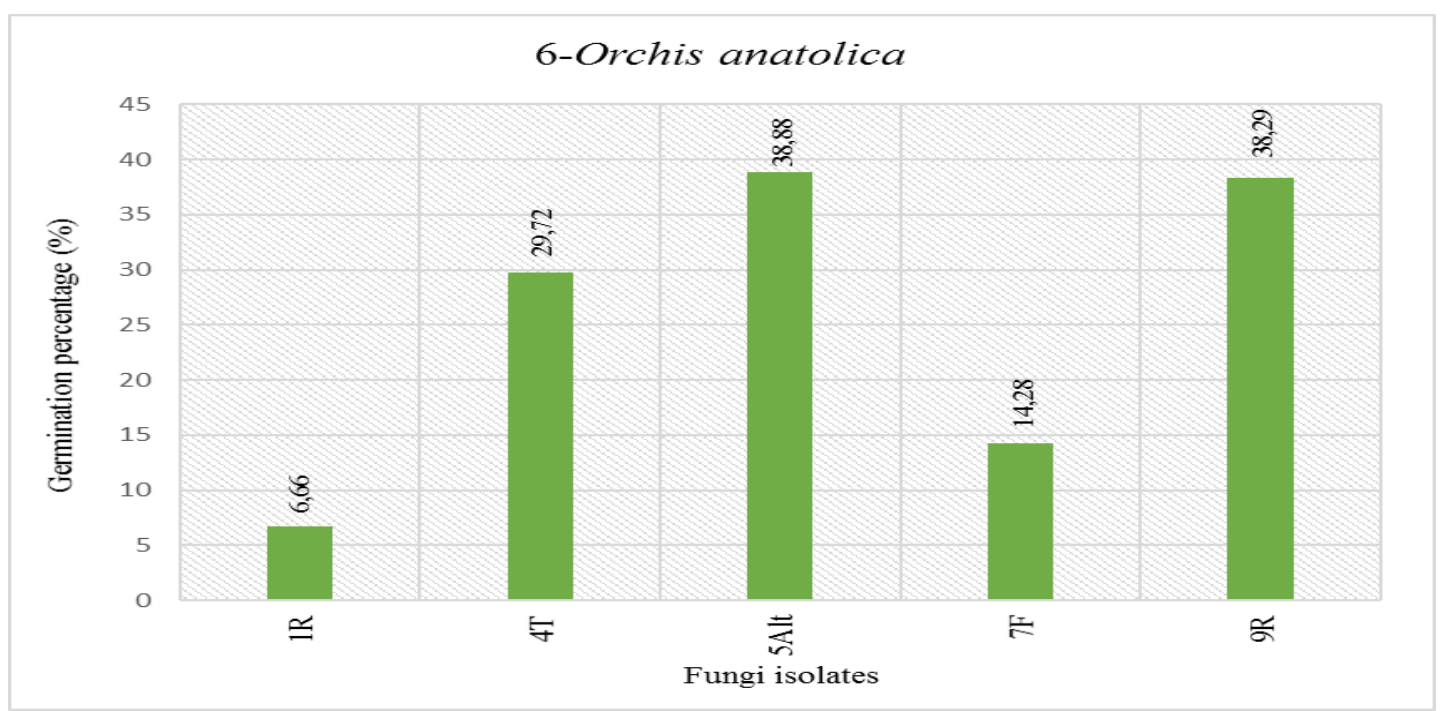

Figure 8. Effects on the germination rates of fungi on O. anatolica germination

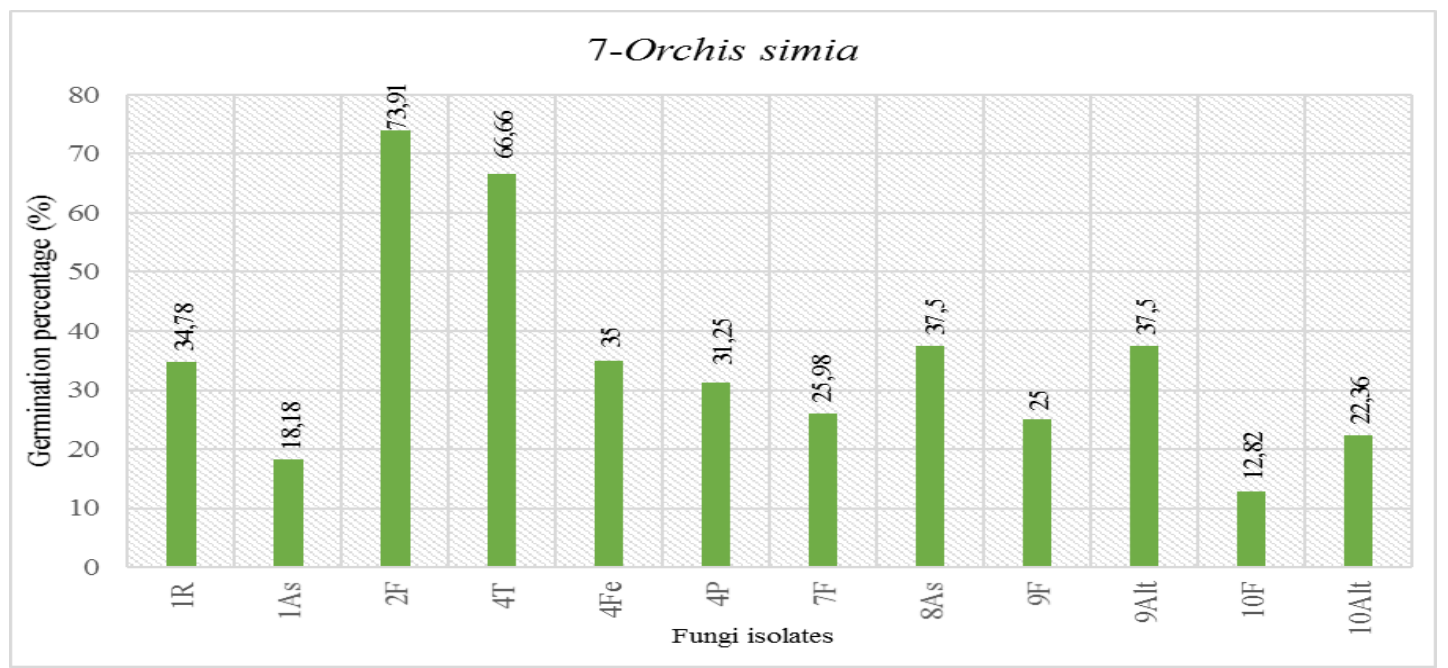

Figure 9. Effects on the germination rates of fungi on $O$. simia germination 


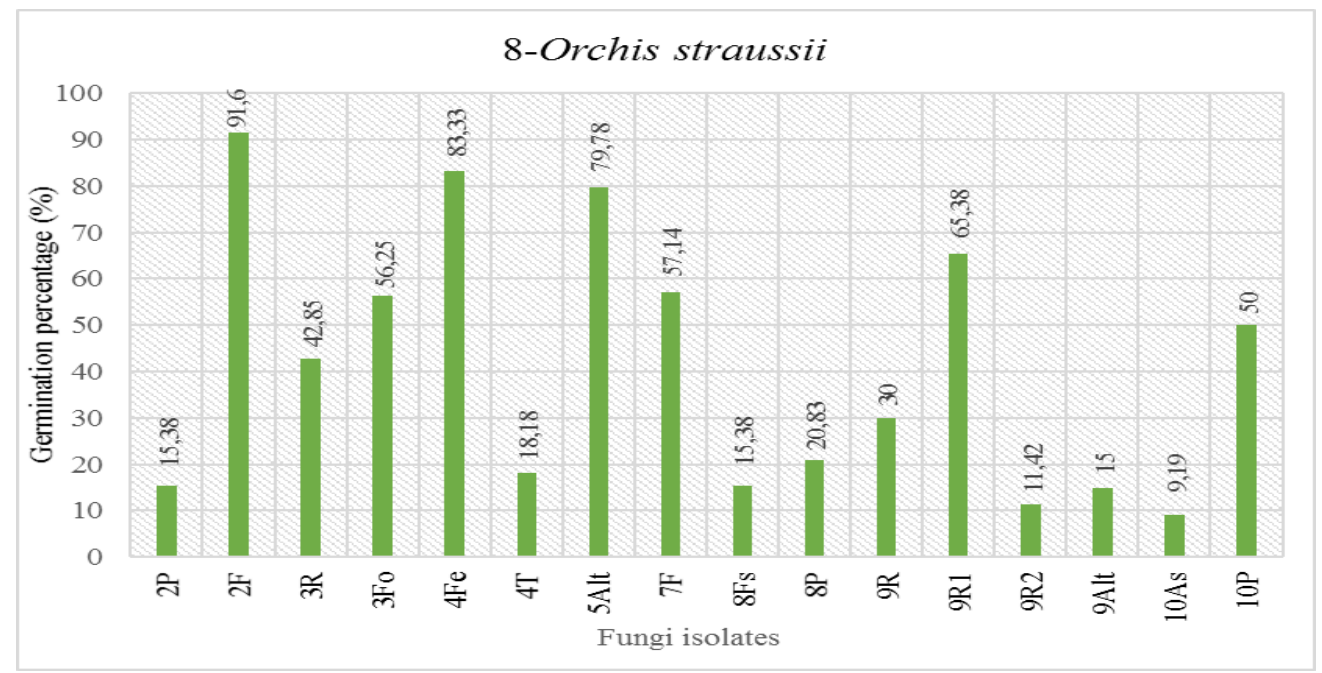

Figure 10. Effects on the germination rates of fungi on $O$. straussii germination

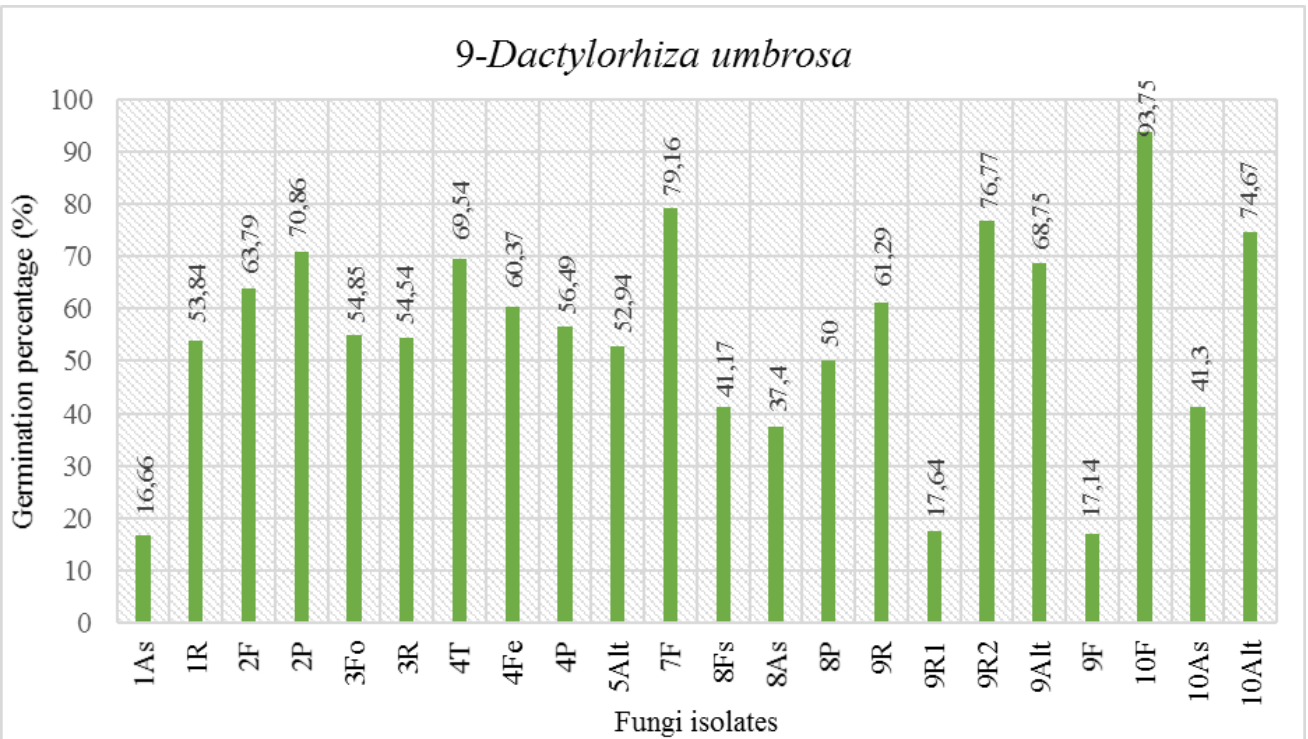

Figure 11. Effects on the germination rates of fungi on D. umbrosa germination

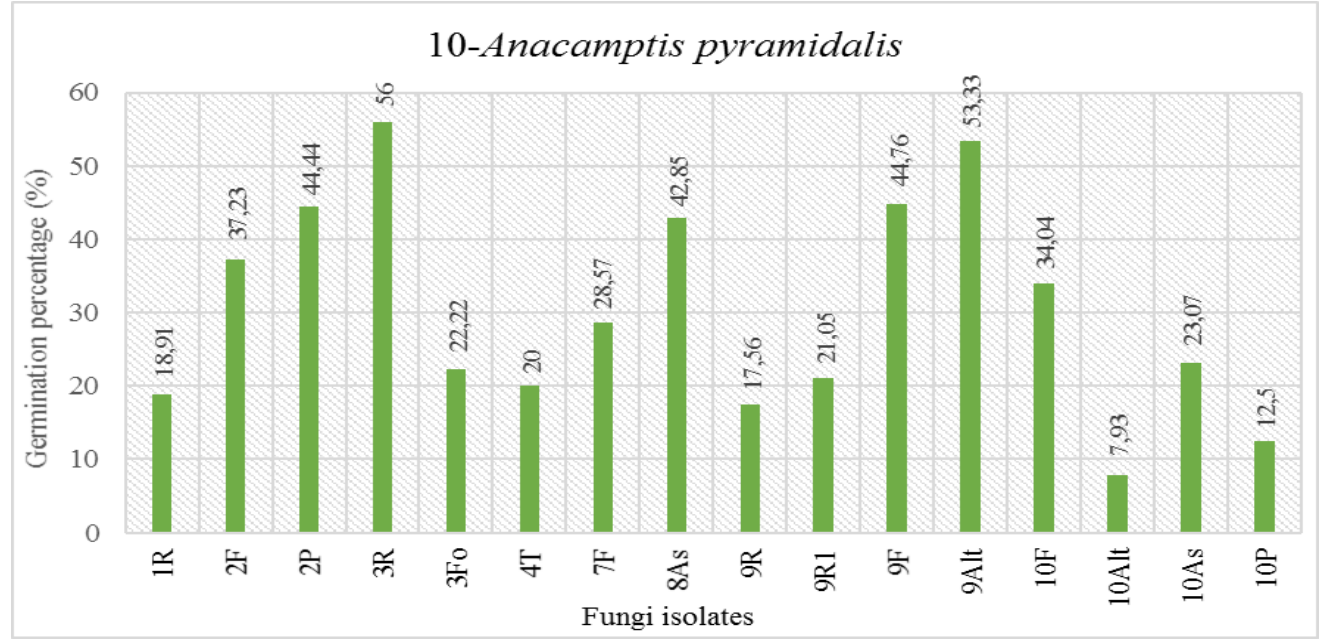

Figure 12. Effects on the germination rates of fungi on A. pyramidalis germination 
Bernard (1909) stated that the symbiotic relationship between the orchid and the fungus is specific to species, while other researchers reported no such specific relation between a mycorrhizal fungus and an orchid species exists (Burgeff, 1936; Curtis, 1939). In another study, it was determined that fungi isolated from orchid tubers were Rhizoctonia, Corticium, Armillaria, Fomes, Hymenochaeta species, while Aspergillus, Penicillium, Phytophtora and Trichoderma were reported to be initiating and promoting germination (Arditti, 1967).

Clements and Ellyard (1979) reported that the effect of the nutrient medium content on symbiotic culture experiments was important for in vitro germination of orchid seeds and suggested primarily to obtain the most effective Rhizoctonia isolate and to prepare the optimal medium for the isolate. In line with this, it has been reported that some fungi have no or little effect on orchid seed germination and the most suitable nutrient medium for controlling parasitic condition is oat medium with additives (Hadley, 1983; Tsutsui and Tomita, 1986). Clements et al. (1986) reported in their study on symbiotic germination of the temperate zone orchids in Europe that Ceratobasidium-like fungi are affective on Dactylorhiza species and Tulasnella-like fungi are affective on Orchis, Ophrys and Serapias orchid species. Researches show that although ground oat added to the symbiotic culture medium used in the studies on Rhizoctonia sp. fungus and orchid seed combination has a stimuli effect on germination, amounts above a certain concentration reduces the degree of stimulation. Smreciu and Currah (1989) have shown that the fungal isolates obtained from an orchid species are symbiotic in germination of another orchid species, and even can act in different development stages of the orchid plant. From 19 fungal isolates isolated from different orchid species collected between March and May in the Eastern Mediterranean Region, 8 pieces of Fusarium sp., 2 pieces of $R$. solani, 2 pieces of Macrophomina sp., 2 pieces of Trichoderma sp., 2 pieces of Pythiaceous sp. and 2 pieces of Absidia sp. fungi are identified (Vakkasoğlu, 1995). 44 out of 47 fungal isolates in a study, in which mycorrhiza forming fungi were isolated from the roots and tubers of various orchid species collected in the Aegean and the Mediterranean Region in April, were identified as Fusarium, while 2 were identifies as Rhizoctonia and 1 was identified as Papulaspora species (Gezgin, 2004). Another study, in which Fusarium sp. was isolated in greater proportions than others, was conducted using Serapias vomeracea subsp. laxiflora and it was determined that they are contaminant (Özkoç, 1991). Alternaria, Aspergillus, Fusarium, Macrophomina, Rhizoctonia, Trichoderma and Verticillium fungi species were isolated from eleven orchid species belonging to Anacamptis, Cephalanthera, Dactylorhiza and Orchis genus collected in Van province (Çı̆̆ and Y1lmaz, 2014). According to the literature, the fungi isolated from orchid tubers in our study stimulate seed germination and plant growth. This is also evident from the results we have obtained. The germination rate varied with species. Not all the orchid species germinated with all fungi. On the contrary, it is observed that one fungal isolate yielding germination success in one species did not achieve the same effect in another one. In some cases, the fungus has not succeeded in germinating the seeds or did not have a high germination rate with the plant it was isolated from. This can be explained by not achieving $100 \%$ of the ecological conditions in the aseptic environment and by the special relationship between the orchid species and the fungus. Özkoç and Dalc1 (1993) reported that not all the isolates had the same effect on Orchis laxiflora seeds cultivated in oat medium (OM) and modified oat medium (MOM) in the presence of 11 fungal isolates brought from different countries and found that two Turkish isolates were 
ineffective in germination. In the germination experiment with 11 fungal isolates in Serapias vomeracea subsp. laxiflora and Orchis laxiflora species, it was observed that not all the isolates did have the same effect (Özkoç, 1991). According to the results obtained from our study, the lowest germination rate in species number 1 was $17.64 \%$ with $\mathrm{T}$ isolate; and the highest germination rate was obtained with $\mathrm{R}$ isolate with $71.19 \%$. In species number 2, the lowest and highest germination rates were found as $31.57 \%$ and $78.26 \%$ respectively with $\mathrm{P}$ isolate. In other species, the lowest and highest germination percentages and fungi isolates in which they are symbiotic were obtained as follows: for species number 3 as $16 \%(\mathrm{R})-27.77 \%(\mathrm{Fo})$; for species number 4 as $27.58 \%(\mathrm{~F})-83.07 \%(\mathrm{R})$; for species number 5 as $10.63 \%(\mathrm{As})-75 \%(\mathrm{~F})$; for species number 6 as $6.66 \%$ (R) - 38.88\% (Alt); for species number 7 as $18.18 \%$ (As) $-73.91 \%$ (F); for species number 8 as $9.19 \%$ (As) - $91.60 \%(\mathrm{~F})$; for species number 9 as $16.66 \%$ (As) $-93.75 \%$ (F) and for species number 10 as $7.93 \%$ (Alt) - 56\% (R).

Successful germination of Dactylorhiza iberica (Bieb. ex Willd.) Soó, Dactylorhiza umbrosa (Kar. et. Kir.) Soó and Orchis palustris Jacquin species with binucleus Rhizoctonia and Rhizoctonia solani isolates in the oat medium and the modified oat medium is achieved (Çı̆ and Yılmaz, 2017). The overall expected effect of Rhizoctonia isolate in orchid germination studies is success, however, as can be seen in our study, Rhizoctonia sp. fungus, which plays a role in seed germination of many species, did not have proportionally the highest average germination figure. When we look at the success rates of fungal isolates along with the ones that cannot stimulate germination, the highest average is provided by Fusarium isolate by $93.75 \%$. In this case, it is clear that fungal isolates and species give different germination success rates together. According to Salifah et al. (2011), a total of 31 different species of fungus was isolated and inoculated onto Grammatophyllum speciosum seed on oat meal agar. The result obtained from the test demonstrated that seed germination rates were best when cocultured with Fusarium sp. number 3. Initial seed germination rates were best when cocultured with Fusarium sp. 3 and Trichoderma sp. 2, yielding an increment in $63.3 \%$ and $55.7 \%$, respectively when compared to the seeds' original size.

The relationship between orchid species and fungal isolates may vary from symbiosis to parasitism, as some researchers have found that parasitic properties of the fungus can increase and unbalance the relationship between the orchid and fungus by depletion of nutrients in the culture medium and fungus might have a parasitic effect in symbiotic environments with high nutrient content (Tomita and Tsutsui, 1988; Özkoç, 1991). Seeds germinated in oat medium were sub-cultured in VWD culture medium. During this process, fungal isolates have developed to such an extent that encapsulates the whole petri dish due to high nutrient concentration and had parasitic effect on germinating seeds. On the other hand, germinated seeds did not have enough required nutrients to develop in oat medium.

Environmental factors such as relative humidity and temperature were reported to have a profound influence on the infectiveness of a variety of fungi (Ibrahim et al., 2011). According to the researches, growth rate of fungi varies depending on temperature and relative humidity. The optimum growth temperatures for the majority of fungi studied was found to fall from 25 to $30{ }^{\circ} \mathrm{C}$ (Sharma and Razak, 2003). For example, the growth of Fusarium oxysporium was found to reach its maximum at $30{ }^{\circ} \mathrm{C}$ after 7 days of incubation which was drastically reduced below $15{ }^{\circ} \mathrm{C}$ and above $35^{\circ} \mathrm{C}$ (Farooq et al., 2005). As can be seen, for a successful orchid germination protocol, both fungi and seeds enter into symbiotic life together with the common satisfaction of them. 


\section{Conclusions}

As a result of the study, different germination success rates were achieved in each orchid species in the presence of fungal isolates. The idea of using a more diluted media during sub-culturing or even using temperature applications to control fungal growth will be given in the methodology section of subsequent new studies to be undertaken with consideration of culture media in which germination took place. But the most important step that must be taken before anything else is to make a molecular identity in order to reveal the true identity of the isolated fungi.

Acknowledgements. This study is supported with the project no 2013-SiÜZIR-Z2 by Siirt University Coordinator of Scientific Research and Projects.

\section{REFERENCES}

[1] Alexander, C., Hadley, G. (1983): Variation in symbiotic activity of Rhizoctonia isolates from Goodyera repens mycorrhizas. - Transactions of the British Mycological Society 152: 99-106.

[2] Arditti, J. (1967): Factor affecting the germination of orchid seeds. - Bot Rev 33: 1-97.

[3] Barnett, H. L. (1965): Illustrated Genera of Imperfect Fungi. 2th ed. - Burges Publishing Company, USA.

[4] Batty, A. L., Dixon, K. W., Brundrett, M., Sivasithamparam, K. (2001): Constraints to symbiotic germination of terrestrial orchid seed in a Mediterranean bushland. - New Phytologist 152: 511-520.

[5] Bernard, N. (1909): L'evolution Dans La Symbiobe. - Annis Sci Nat (Bot.) Se'r 9.9.1.

[6] Bonnardeaux, Y., Brundrett, M., Batty, A., Dixon, K., Koch, J., Sivasithamparam, K. (2007): Diversity of mycorrhizal fungi of terrestrial orchids: compatibility webs, brief encounters, lasting relationships and alien invasions. - Mycol. Res 111: 51-61.

[7] Booth, C. (1971): The Genus Fusarium. - Commonwealth Mycological Institute, Kew, Surrey, England.

[8] Burgeff, H. (1936): Die Samenkeimung der Orchideen. - G. Fischer, Jena.

[9] Burgess, L. W., Summerell, B. A., Bullock, S., Gott, K. P., Backhouse, D. (1994): Laboratory Manual for Fusarium Research. 3rd ed. - University of Sidney and Royal Botanical Gardens, Sidney.

[10] Clements, M. A., Ellyard, R. K. (1979): The symbiotic germination of Australian terrestrial orchids. - Amer Orchid Soc Bull 48: 810-816.

[11] Clements, M. A., Muir, H., Cribb, P. J. (1986): A preliminary report on the symbiotic germination of European terrestrial orchids. - Kew. Bull. 41(2): 437-445.

[12] Curtis, J. T. (1939): The relation of specificity of orchid mycorrhizal fungi to the problem of symbiosis. - Amer. J. Bot. 26: 390-399.

[13] Çı̆̆, A., Yılmaz, H. (2014): Bazı orkide türlerinde farklı yöntemlerle izole edilen funguslar. - Türkiye Tarımsal Araştırmalar Dergisi 1: 24-28.

[14] Çı̆̆, A., Yılmaz, H. (2017): In vitro symbiotic culture studies of some orchid species. Journal of Agricultural Sciences23: 453-463.

[15] Davis, P. H. (1984): Flora of Turkey and the East Aegan Islands. Volume: 8. - Edinburgh University Press, Great Britain.

[16] Domsch, K. H., Gams, W. T., Anderson, H. (1980): Compendium of Soil Fungi. Academic Press, London.

[17] Düzgünes, O., Kesici, T., Kavuncu, O., Gürbüz, F. (1987): Arastırma ve Deneme Metotları. - Yayın No: 1021, Ders Kitabı: 295, A. Ü. Ziraat Fakültesi Yayınları, Ankara. 
[18] Farooq, S., Iqbal, S. M., Abdulrauf, C. (2005): Physiological studies of Fusarium oxysporum. - Inter J Agric Bio 7(2): 275-277.

[19] Gezgin, Y. (2004): Çeşitli Salep (Orkide) Türlerinde Mikoriza Oluşturan Fungusların İzolasyonu ve Tanımlanması ile İnokulant Olarak Kullanım Olanaklarının İncelenmesi. MSc. Ege University, İzmir, Turkey.

[20] Gilman, J. C. (1959): A Manual of Soil Fungi. - The Iowa State University Press, USA.

[21] Google Earth (2018): https://earth.google.com. - Accessed on 04.07.2018.

[22] Hadley, G. (1983): Symbiotic germination of orchid seed. - The Orchid Review 1983(2): 44-47.

[23] Ibrahim, M., Rabah, A. B., Liman, B., Ibrahim, N. T. (2011): Effect of temperature and relative humidity on the growth of Helminthosporium fulvum. - Nigerian Journal of Basic and Applied Science 19(1): 127-129.

[24] Ingold, C. T., Hudson, H. J. (1993): The Biology. 6th ed. - Chapman Hall, London.

[25] Muir, H. J. (1989): The Role of Physiology Ecology and Management. - In: Pritchard, H. W., (ed.) Modern Methods in Orchid Conservation. - Cambridge University Press, Cambridge, UK, pp. 39-56.

[26] Ogoshi, A. (1975): Grouping of Rhizoctonia solani Kühn and their perfect stages. Review Plant Protection Research 8: 93-103.

[27] Otero, J. T., Ackerman, J. D., Bayman, P. (2004): Differences in mychorrhizal preferences between two tropical orchids. - Molecular Ecology 13: 2393-2404.

[28] Özkoc, İ. (1991): Serapias vomeracea (Burm fil.) Briq. subsp. laxiflora (Soo) Gölz et. Reinhard ve Orchis laxiflora Lam. (Orchidacea) Tohumlarını Simbiyotik ve Asimbiyotik Kültürlerde Çimlenme ve Gelişmesi Üzerinde Araştırılması. - Dr. Thesis. Ondokuz Mayıs University, Samsun, Turkey.

[29] Özkoç, İ., Dalcı, M. (1993): Orchis laxiflora tohumlarının iki farklı ortamda çimlenmesi ve gelişmesi üzerine bazı fungusların etkisi. - Doğa Türk Biyoloji Dergisi 17(1): 23-28.

[30] Salifah, H. A. B., Muskhazli, M., Rusea, G., Nithiyaa, P. (2011): Variation in mycorrhizal specificity for in vitro symbiotic seed germination of Grammatophyllum speciosum Blume. - Sains Malaysiana 40(5): 451-455.

[31] Samuels, G. J., Chaverri, P., Farr, D. F., MC Cray, E. B. (2006): Trichoderma Online, Systematic Botany \& Mycology Laboratory, ARS, USDA. - http://nt.arsgrin.gov/taxadescriptions/keys/trichodermaindex.cfm. Accessed on 12/07/2005.

[32] Sezik, E. (1984): Orkidelerimiz, Türkiye'nin Orkideleri. - Sandoz Kültür Yayınları 6: 166.

[33] Sharma, J., Zettler, L. W., Van Sambeek, J. W., Ellersieck, M. R., Starbuck, C. J. (2003): Symbiotic seed germination and mycorrhiza of federally threatened Platenthera praeclara (Orchidaceae). - Am Midl Nat 149: 104-120.

[34] Sharma, R., Razak, R. C. (2003): Keratinophilic fungi: natural keratin degrading machines; their isolation, identification and ecological role. - Resonance 2003(9): 28-30.

[35] Singh, K., Frisvad, J. C., Thrane, U., Mathur, S. B. (1991): An Illustrated Manual on Identification of Same Seed-Borne Aspergilli, Fusaria, Penicillia and Their Mycotoxins. Danish Government Institute for Seed Pathology for Developing Countries, Hellerup, Denmark.

[36] Smreciu, E. A., Currah, R. S. (1989): Symbiotic germination of seeds of terrestrial orchids of North America and Europe. - Lindleyana 1(4): 6-16.

[37] Steinfort, U., Verdugo, G., Besoain, X., Cisternas, M. A. (2010): Mycorrhizal association and symbiotic germination of the terrestrial orchid Bipinnula fimbriata (Poepp.) Johnst (Orchidaceae). - Flora - Morphology, Distribution, Functional Ecology of Plants 205(12): 811-817.

[38] Tomita, M., Tsutsui, K. (1988): the effects of the concentration of powdered oats in the medium on the growth of symbiotic seedlings of Spiranthes sinensis Ames and Liparis nervosa Lindl. - J Fac Agr Hokkaido Univ 63(4): 354-362. 
[39] Tsutsui, K., Tomita, M. (1986): Symbiotic germination of Spiranthes Sinensis Ames associated with some orchid endophytes. - J Fac Agr Hokkaido Univ 62(4): 440-451.

[40] Vakkasoğlu, F. (1995): Orkidelerde Mikorizal Fungusların Orkide Tohumlarının Çimlenmesi ve Büyümeleri Üzerine Etkisi. - MSc. Çukurova University, Adana, Turkey.

[41] Van Waes, J. M., Debergh, P. C. (1986): In vitro germination of some western European orchids. - Physiol. Plant 67(2): 253-261.

[42] Warcup, J. H. (1971): Specificity of mycorrhizal associations in some Australian terrestrial orchids. - New Phytologist 70: 41-46.

[43] Zettler, L. W., Steward, S. L., Bowles, M. L., Jacobs, K. A. (2001): Mycorrhizal fungi and cold-assited symbiotic germination of the federally threatened eastern prairie fringed orchid, Platenthera leucophaea (Nuttall) Lindley. - Am Midl Nat 145: 168-175. 